\title{
Surface Structure of Bacteroides nodosus in Relation to Virulence and Immunoprotection in Sheep
}

\author{
By DALE EVERY AND T. MARTIN SKERMAN* \\ Wallaceville Animal Research Centre, Research Division, Ministry of Agriculture \& Fisheries, \\ Private Bag, Upper Hutt, New Zealand
}

(Received 6 April 1982)

\begin{abstract}
A comparative electron microscopic study was made of virulent ovine strains, benign ovine strains, bovine strains and culture variants of Bacteroides nodosus using negative staining, thin section and freeze-fracture etch techniques. The plasma membrane, peptidoglycan layer and outer membrane structures were similar in all the organisms, but there were marked differences in the presence of pili, diffuse polar material and additional layer. The variations in these surface structures were examined in relation to the virulence and immunoprotection of $B$. nodosus towards foot-rot in sheep. Only organisms with abundant pili caused virulent foot-rot; diffuse polar material and perhaps the additional layer may also be associated with virulence, but conclusive evidence was lacking. It appeared that pili and one or more unknown cell components, possibly diffuse polar material but not the additional layer, were necessary for immunoprotection.
\end{abstract}

\section{INTRODUCTION}

Bacteroides nodosus has been characterized from cases of virulent foot-rot in sheep (Beveridge, 1941), benign foot-rot in sheep (Thomas, 1962; Egerton \& Parsonson, 1969) and interdigital dermatitis in cattle (Laing \& Egerton, 1978). Variants derived by in vitro subculture of virulent strains of $B$. nodosus have also been described (Thorley, 1976; Skerman et al., 1981) and shown to be of low or no virulence towards sheep. Comparative studies have been made on these organisms to determine whether the virulent ovine strains have any distinguishing biochemical or ultrastructural characteristics that may be associated with their pathogenicity and immunoprotective properties in sheep (Egerton \& Parsonson, 1969; Short et al., 1976; Depiazzi \& Richards, 1979; Stewart, 1979; Skerman et al., 1981; Every, 1982). Virulent strains have distinct extracellular proteinase characteristics which correlate with virulence (Egerton \& Parsonson, 1969; Depiazzi \& Richards, 1979; Stewart, 1979; Skerman et al., 1981; Every, 1982) but apparently not with vaccine efficacy (Stewart, 1978). The only ultrastructural feature associated with virulence and/or protective immunity is the presence of pili (Short et al., 1976; Stewart, 1978; Thorley \& Egerton, 1981).

Several new structures within the cell envelope and on the surface of virulent strains of $B$. nodosus have been described (Every \& Skerman, 1980). This paper reports the distribution of these structures on various isolates, and variants of $B$. nodosus and their possible association with virulence and immunoprotective properties.

\section{METHODS}

Organisms. Bacteroides nodosus strains 65 and 91 were isolated from clinical cases of ovine foot-rot in New Zealand. Strains 141 and 142 were isolated from interdigital dermatitis in New Zealand cattle. Strain ATCC 25549, an ovine isolate, was obtained from the American Type Culture Collection. Strain A198 from virulent foot-rot and A134, A178, A305 from benign foot-rot were isolated from Australian sheep and were obtained from the McMaster Laboratory, Division of Animal Health, CSIRO, Sydney, Australia. The prefix A is used to distinguish them from New Zealand strains. 
Bacteroides nodosus culture variants were derived from serially passaged liquid cultures of wild-type strains as described by Skerman et al. (1981). The mucoid colony-type variant $91 \mathrm{M}$ and the circular colony-type variant $91 \mathrm{C}$ were derived from strain 91 which produced a beaded colony-type on agar. The mucoid colony-type variant A198M was derived from a beaded colony type strain A198.

Virulence and immunoprotection tests were performed as described previously (Skerman et al., 1981).

Culture methods. Cultures were grown anaerobically at $37^{\circ} \mathrm{C}$, either in liquid trypticase/arginine/serine medium for 24 to $48 \mathrm{~h}$ or on agar maintenance medium for 4 to $5 \mathrm{~d}$ as described by Skerman (1975).

Electron microscopy. Uranyl acetate or potassium phosphotungstate were used for negative staining of intact bacteria and cell walls (Every \& Skerman, 1980). Uranyl acetate was preferred for assessment of pili numbers. Cell walls were prepared by sonic disintegration and differential centrifugation (Every \& Skerman, 1980). Thin sections were prepared and stained with uranyl acetate and lead citrate (Every \& Skerman, 1980) or with ruthenium red (Cagle et al., 1972). Bacteria were freeze-etched (Moor \& Mühlethaler, 1963) in the presence or absence of glycerol (Every \& Skerman, 1980). Specimens were examined in a Philips EM201C electron microscope at $60 \mathrm{kV}$ with a $50 \mu \mathrm{m}$ objective aperture.

\section{RESULTS}

\section{Negatively stained whole bacteria}

Pili were present in widely varying numbers on all B. nodosus examined (Fig. 1 and Table 1), but the pili morphology was the same in all cases. A few bacteria from some cultures of the virulent strains had more than 200 pili per cell, whereas at the other extreme, the avirulent culture variant $91 \mathrm{C}$ usually had only one pilus per cell on less than $2 \%$ of the bacteria and in some cultures none of the bacteria had pili.

Except for culture variant $91 \mathrm{C}$, the number of pili per cell within a single population varied widely (Fig. 2). This variation did not diminish even after 40 selective transfers of a specific colony-type on agar. Also, the average number of pili per cell remained high, though variable from culture to culture, on successive agar subcultures of beaded colony-type virulent strains. In

\section{Table 1. B. nodosus strains and culture variants: their surface structures, virulence and immunoprotective properties}

\begin{tabular}{|c|c|c|c|c|c|c|}
\hline $\begin{array}{c}\text { Source of } \\
\text { bacteria }\end{array}$ & $\begin{array}{l}\text { B. nodosus } \\
\text { strain }\end{array}$ & Virulence* & $\begin{array}{c}\text { Immuno- } \\
\text { protection } \dagger\end{array}$ & Pilił & $\begin{array}{l}\text { Additional } \\
\text { layer } \$\end{array}$ & $\begin{array}{c}\text { Diffuse } \\
\text { polar } \\
\text { material|| }\end{array}$ \\
\hline $\begin{array}{l}\text { Virulent } \\
\text { ovine } \\
\text { foot-rot }\end{array}$ & $\begin{array}{l}\text { A198 } \\
\text { ATCC } 25549 \\
91 \\
65\end{array}$ & $\begin{array}{l}++ \\
++ \\
++ \\
++\end{array}$ & $\begin{array}{l}++ \\
++ \\
++ \\
++\end{array}$ & $\begin{array}{l}+++ \\
+++ \\
+++ \\
+++\end{array}$ & $\begin{array}{l}+ \\
+ \\
+ \\
+\end{array}$ & $\begin{array}{l}+ \\
+ \\
+ \\
+\end{array}$ \\
\hline $\begin{array}{l}\text { Benign } \\
\text { ovine } \\
\text { foot-rot }\end{array}$ & $\begin{array}{l}\text { A134 } \\
\text { A178 } \\
\text { A305 }\end{array}$ & $\begin{array}{l}+ \\
+ \\
+\end{array}$ & $\begin{array}{l}\text { NT } \\
\text { NT } \\
\text { NT }\end{array}$ & $\begin{array}{l}+ \\
+ \\
+\end{array}$ & $\begin{array}{l}+ \\
+ \\
+\end{array}$ & $\begin{array}{l}- \\
- \\
+\end{array}$ \\
\hline $\begin{array}{l}\text { Bovine } \\
\text { interdigital } \\
\text { dermatitis }\end{array}$ & $\begin{array}{l}141 \\
142\end{array}$ & $\begin{array}{l}+ \\
+\end{array}$ & $\begin{array}{l}\text { NT } \\
\text { NT }\end{array}$ & $\begin{array}{l}+++ \\
++\end{array}$ & $\begin{array}{l}+ \\
+\end{array}$ & $\begin{array}{l}- \\
-\end{array}$ \\
\hline $\begin{array}{l}\text { In vitro } \\
\text { culture } \\
\text { variants }\end{array}$ & $\begin{array}{l}\text { A198M } \\
91 \mathrm{M} \\
91 \mathrm{C}\end{array}$ & $\begin{array}{l}+ \\
+ \\
-\end{array}$ & $\begin{array}{l}+ \\
+ \\
+\end{array}$ & $\begin{array}{l}+ \\
+ \\
-\end{array}$ & $\begin{array}{l}+ \\
+ \\
-\end{array}$ & $\begin{array}{l}+ \\
+ \\
+\end{array}$ \\
\hline
\end{tabular}

* Virulence was assessed from the development of foot lesions after artificial infection of Merino sheep in heated pens (Skerman et al., 1981); + +, progressive virulent foot-rot; +, non-progressive foot-rot (scald); - , no progressive foot-rot or scald.

+ Immunoprotection was assessed in vaccine-challenge trials (Skerman et al., 1981);,$++ 80-100 \%$ sheep resistant to homologous artificial challenge;,$+ 30-40 \%$ sheep resistant to challenge with homologous prototype strain; NT, not tested because homologous challenge infection was not feasible.

$\ddagger$ Numbers of pili per bacterium were assessed on negatively stained bacteria (see Methods) +++ , average of 50 or more pili; ++ , average of $20-50$ pili; + , average of $1-10$ pili; - , less than $2 \%$ of bacteria with 1 pilus.

$\S$ The presence $(+)$ or absence $(-)$ of the additional layer was assessed on sonically disrupted bacteria, in thin sections and in freeze-etch preparations (see Methods).

$\|$ The presence $(+)$ or absence $(-)$ of diffuse polar material was assessed on longitudinal thin sections. 

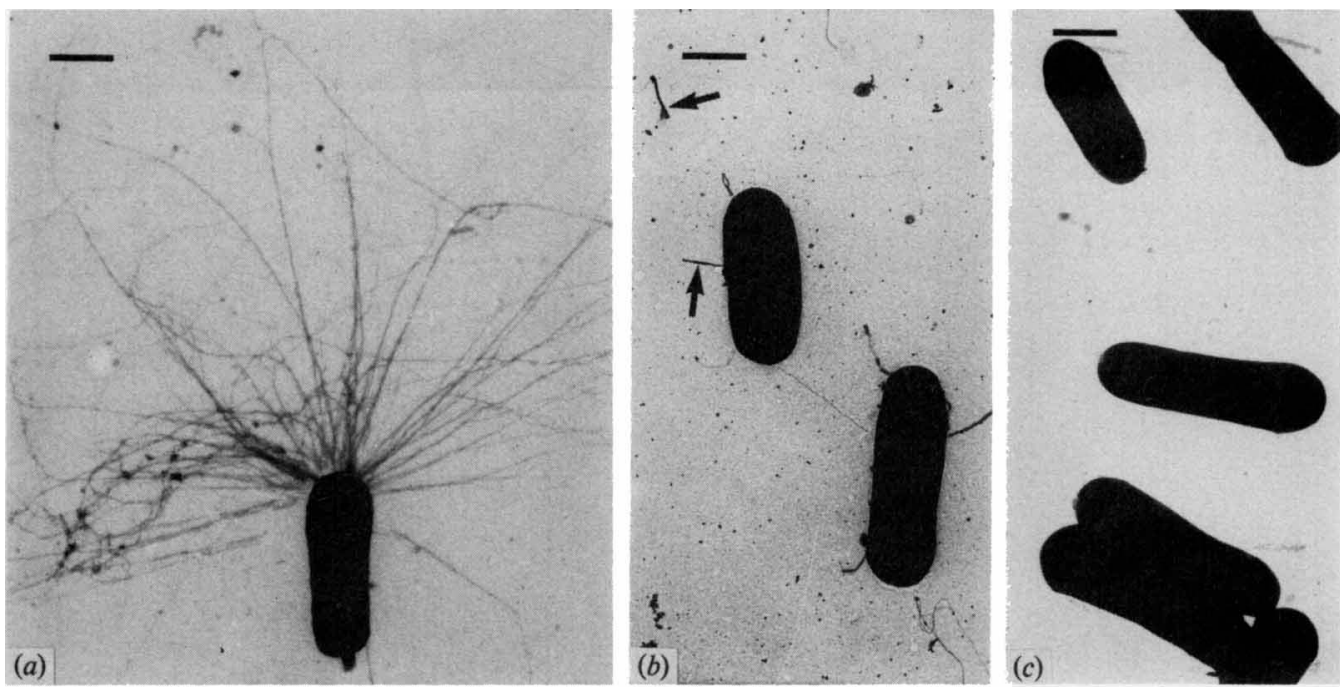

Fig. 1. (a) B. nodosus virulent foot-rot strain 91 grown in liquid culture and negatively stained with uranyl acetate. Numerous pili emerge from one pole. (b) B. nodosus culture variant $91 \mathrm{M}$ grown in liquid culture and negatively stained with uranyl acetate. Only a few pili emerge from the bacteria, and rodlike structures are present (arrow). (c) B. nodosus culture variant $91 \mathrm{C}$ grown in liquid culture and stained with uranyl acetate. No pili are present. The bar markers represent $1 \mu \mathrm{m}$.

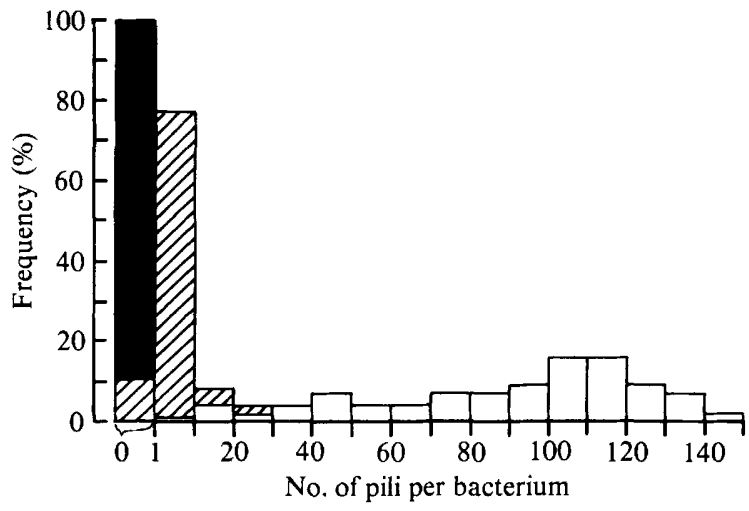

Fig. 2. Frequency distribution of pili per bacterium in liquid culture populations of $B$. nodosus. Over 200 bacteria from each population were examined. $\square$, strain $91 ; \square$, culture variant $91 \mathrm{M} ; \square$, culture variant $91 \mathrm{C}$. The frequency distribution in other strains resembled strain 91 .

contrast, serial passage of some strains in liquid cultures gave rise to the mucoid and circular colony variants with low numbers of pili (Table 1). The relationship between the number of pili per cell, virulence and immunoprotective properties of various strains and variants of $B$. nodosus is shown in Table 1.

\section{Negatively stained bacterial fragments}

Fragments of the cell wall in the form of rod-like structures (Fig. $1 b$ ) were observed in liquid cultures of all strains and variants except $91 \mathrm{C}$, which did, however, show rod-like structures in some agar cultures.

Cell walls from all sonically disrupted $B$. nodosus showed polar ring structures (prs) (Figs 3 and 4). A regularly striated additional layer (Fig. 3 ) covered the prs on all strains and variants except 91C (Fig. 4). 

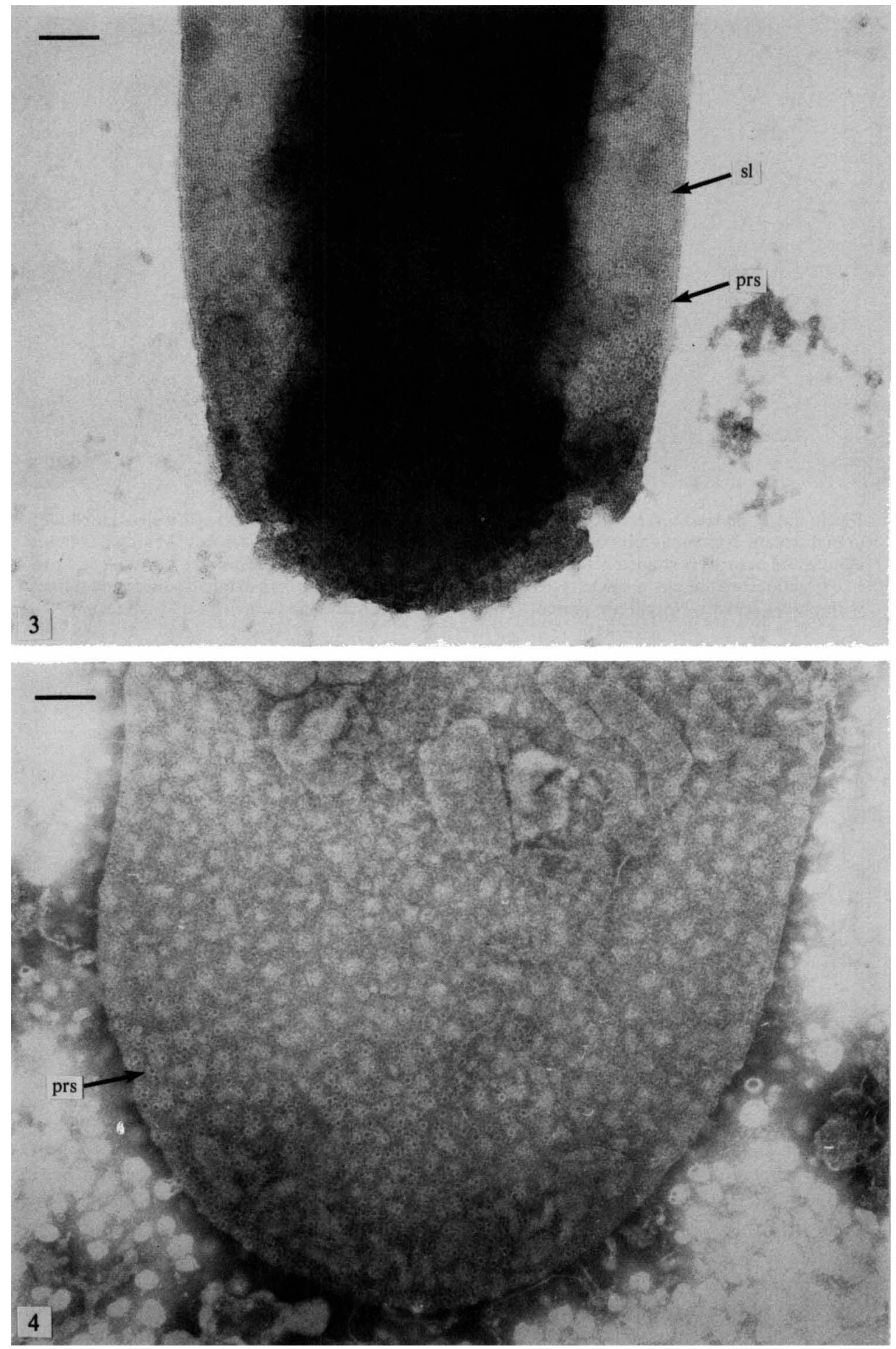

Fig. 3. Cell wall fragment from $B$. nodosus bovine strain 141 prepared by sonication and differential centrifugation and stained with potassium phosphotungstate. Polar ring structures (prs) are present on the pole of the bacterium and a striated layer (sl) covers the whole surface. The bar marker represents $0 \cdot 1 \mu \mathrm{m}$.

Fig. 4. Cell wall fragment from $B$. nodosus culture variant $91 \mathrm{C}$ prepared as for Fig. 3. Polar ring structures but no striated layer, are present on the surface. The bar marker represents $0.1 \mu \mathrm{m}$. 

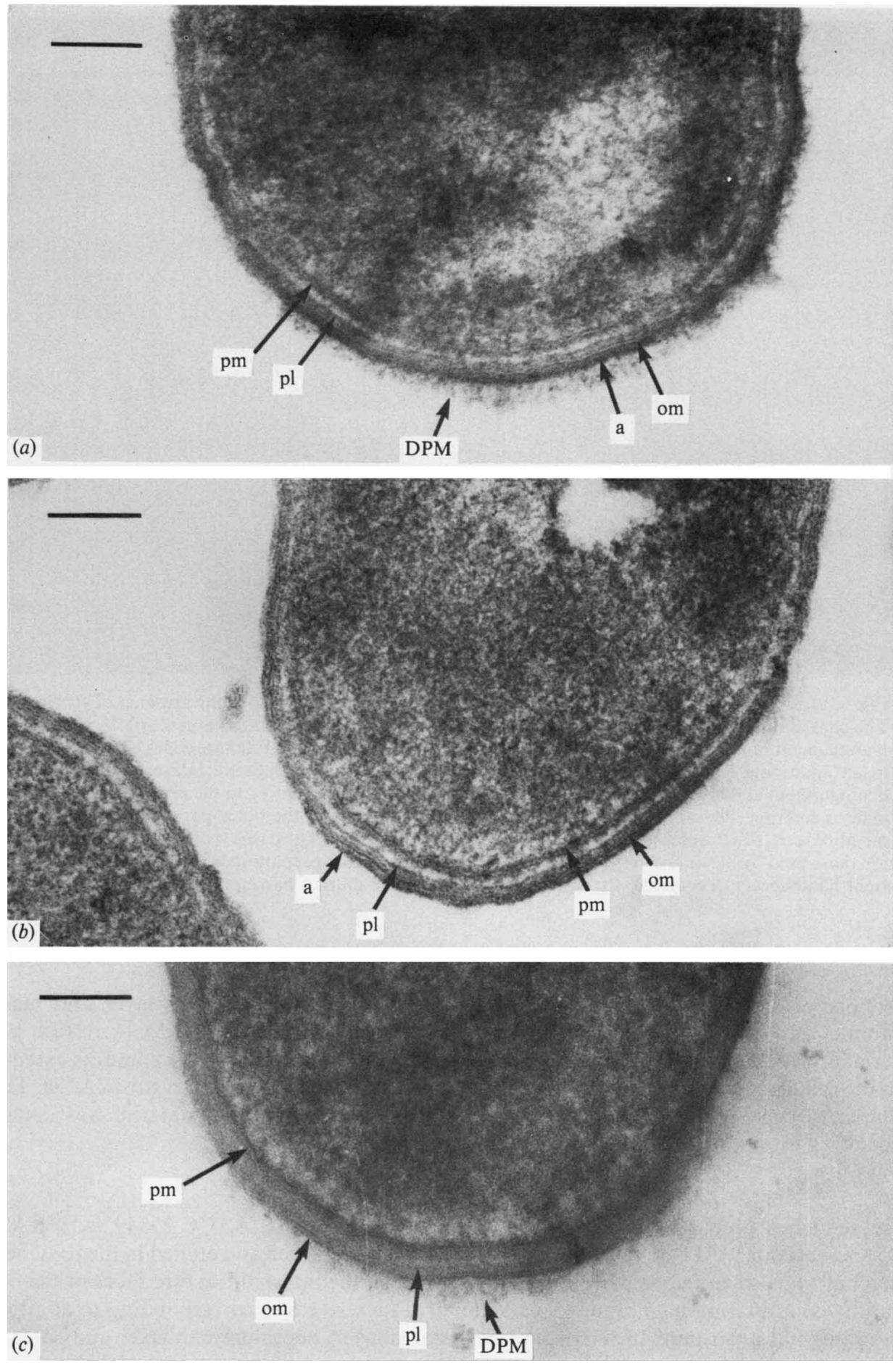

Fig. 5. (a) Part of a longitudinal thin section of B. nodosus benign foot-rot strain A305 from a liquid culture showing the plasma membrane ( $\mathrm{pm})$, peptidoglycan layer ( $\mathrm{pl})$, outer membrane (om), additional layer (a) and diffuse polar material (DPM). (b) Part of a longitudinal thin section of $B$. nodosus bovine strain 142 showing pm, pl, om, a, but no DPM. (c) Part of a longitudinal thin section of $B$. nodosus culture variant $91 \mathrm{C}$ showing $\mathrm{pm}, \mathrm{pl}$, om, DPM but no additional layer. The bar markers represent $0 \cdot 1 \mu \mathrm{m}$. 


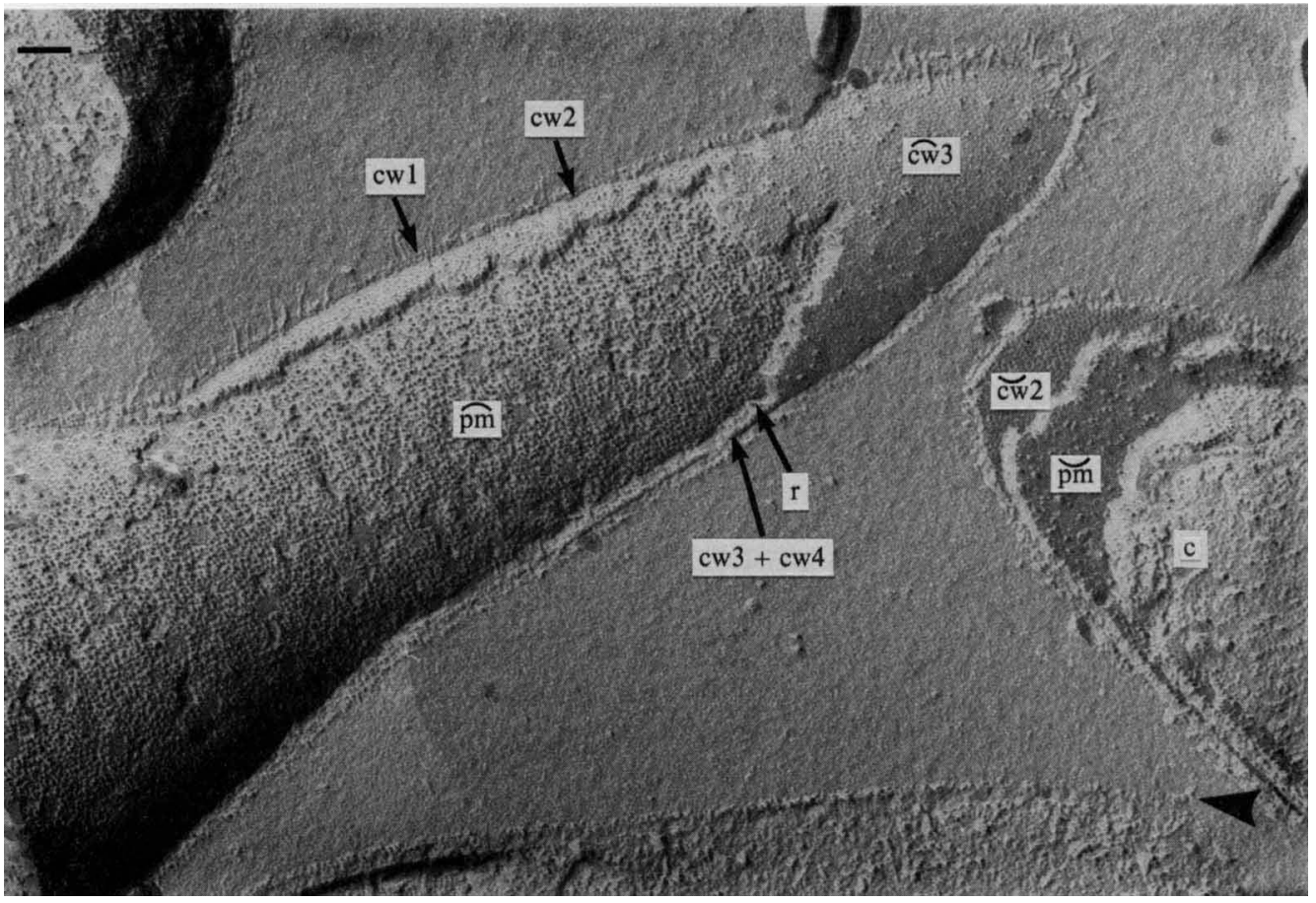

Fig. 6. B. nodosus culture variant $91 \mathrm{M}$ obliquely freeze-fractured and etched in the presence of glycerol. The convex and concave views of the cell envelopes show details of the internal fracture faces of the plasma membrane ( $\mathrm{pm}$ and $\mathrm{pm}$ ) and the outer membrane ( $\mathrm{cw} 3$ and $\mathrm{cw} 2)$. Fracture edges corresponding to an additional layer (cw1) and the outer portion of the outer membrane bilayer (cw2) can be distinguished. Only two fracture edges can be distinguished corresponding to the inner portion of the outer membrane bilayer (cw3), the peptidoglycan layer (cw4) and the outer portion of the plasma membrane (r). Fractures through the cytoplasm (c) are also present. The terms for the various structures are those used by Sleytr $e t$ al. (1974). In all the freeze-fracture etch preparations the arrow in the lower right hand corner denotes the shadowing direction and the marker bar represents $0.1 \mu \mathrm{m}$.

\section{Thin sections}

Sections of all $B$. nodosus showed an outer membrane, peptidoglycan layer and plasma membrane and all except variant $91 \mathrm{C}$ showed an additional layer (Fig. 5). A diffuse polar material (DPM, Fig. 5a) was present on some strains and variants (Table 1), and its extension from the cell envelope varied from $70 \mathrm{~nm}$ in strain ATCC 25549 to $25 \mathrm{~nm}$ in strain A198. There appeared to be less DPM in stationary phase bacteria. No capsular material was detected surrounding any of the bacteria using ruthenium red stain.

\section{Freeze-etched preparations}

Freeze-etched preparations were made only of strains 141, 91, ATCC 25549, A198, A134, A305 and variants $91 \mathrm{M}$ and $91 \mathrm{C}$. Preparations obliquely fractured and etched in the presence of glycerol all showed the same morphological features on the internal fracture faces of the outer membrane and plasma membrane (Figs 6 and 7). Fracture edges corresponding to additional layer, outer and inner parts of the outer membrane bilayer, peptidoglycan layer and outer and inner parts of the plasma membrane were present except for variant $91 \mathrm{C}$ which lacked a fracture edge corresponding to the additional layer. Cross-fractures of the cell envelope of variant $91 \mathrm{C}$ also lacked an edge corresponding to the additional layer (Fig. 8).

All the strains and variants examined had large pits in the polar region of the internal concave fracture face of the outer membrane. A good example of these structures hexagonally arranged and with the appearance of craters with raised edges and central domes is shown in Fig. 7(b). 

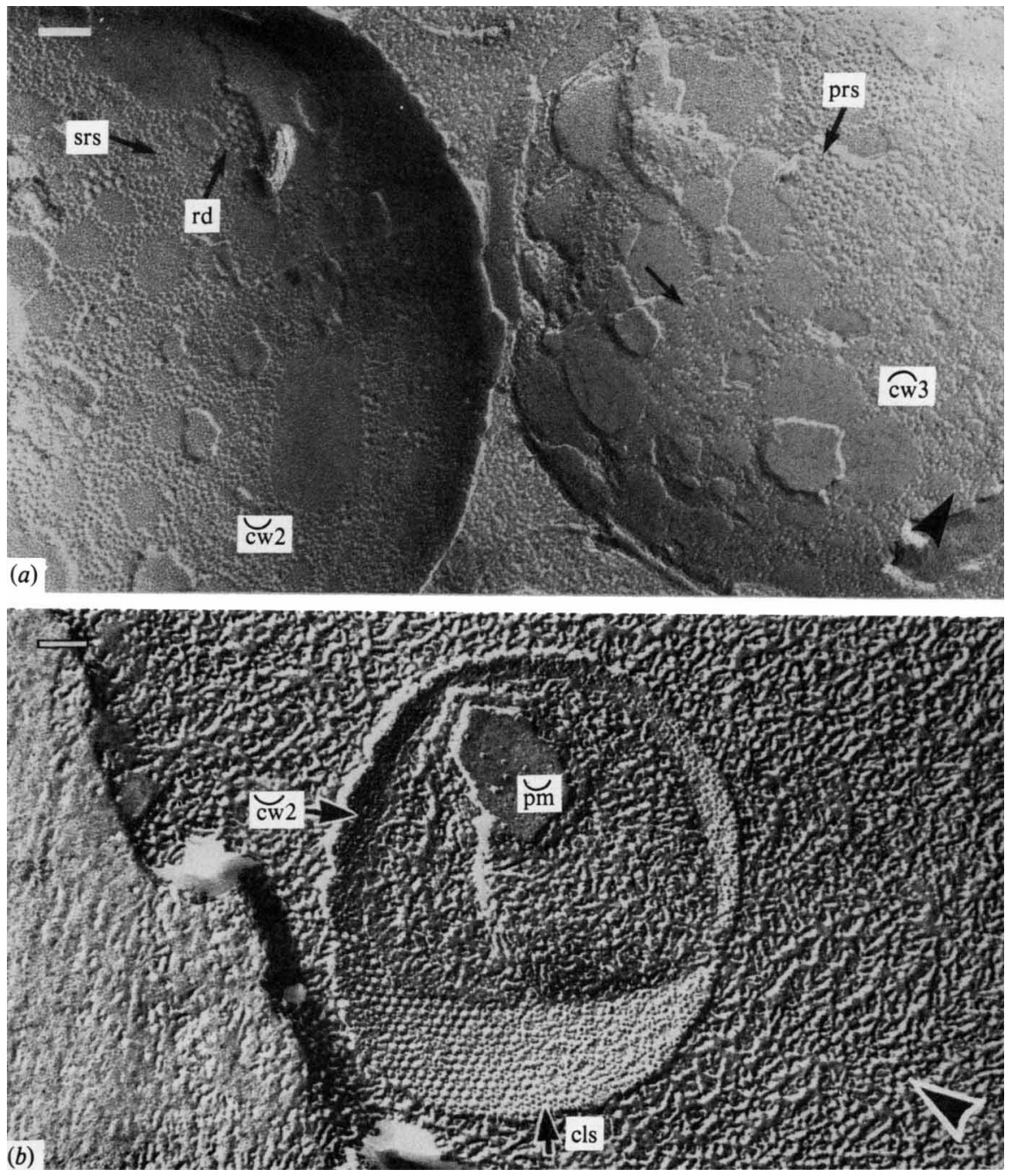

Fig. 7. (a) B. nodosus culture variant $91 \mathrm{C}$ freeze-fractured and etched in the presence of glycerol. Two bacteria were obliquely fractured through their polar regions. The concave view of the outer portion of the outer membrane (cw2) has hexagonally arranged pits or ring-shaped depressions (rd) and small ring structures (srs) on its surface. The convex view of the inner portion of the outer membrane (cw 3 ) has raised polar ring structures (prs) and small pits (arrow) on its surface. The terms for these structures on the fracture faces are those used by Every \& Skerman (1980). (b) B. nodosus culture variant $91 \mathrm{C}$ freezefractured and etched in the presence of glycerol. Hexagonally arranged crater-like structures with central domes (cls) are present on cw2.

Sometimes the central dome was not visible so that the structures looked like raised particles or craters. They had the same centre-to-centre spacing (approx. $20 \mathrm{~nm}$ ) as the complementary shaped polar ring structures shown in Fig. 7(a) which were also seen on all strains and variants examined.

Freeze-etching of $B$. nodosus in the absence of glycerol revealed the hexagonally arranged particles of the additional layer (Fig. $9 a$ ) on all the strains and variants examined except 91C (Fig. $9 b$ ). The etched outer convex surface of the outer membrane was only seen on variant $91 \mathrm{C}$ because in the other specimens it was always obscured by the additional layer. 


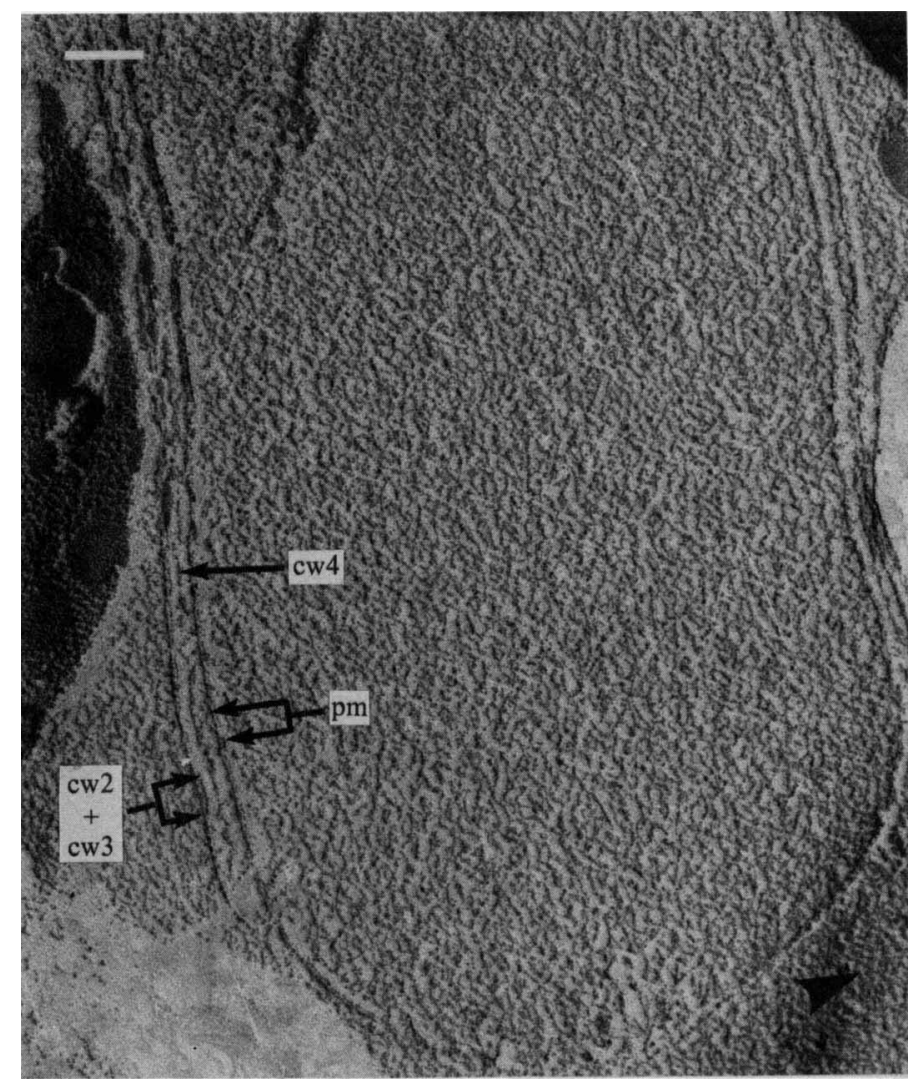

Fig. 8. Cross-fractured cell envelope of $B$. nodosus culture variant $91 \mathrm{C}$ showing the fractured edges of the plasma membrane bilayer (double arrow), the edge of the peptidoglycan layer (cw4), and the double edges of the outer membrane (cw2 $+\mathrm{cw} 3$ ). Note the lack of a fracture edge for additional layer.

\section{DISCUSSION}

This study has shown that in all strains and culture variants of $B$. nodosus, the structure of the plasma membrane, peptidoglycan layer and outer membrane were similar. However, those strains and variants of low immunoprotective activity and/or virulence were distinguished from strains of high virulence and immunoprotective activity by their lack or reduction of one or two of the three surface structures: additional layer, DPM and pili. Hence the possible involvement of these three structures as virulence factors or protective immunogens can be considered. In addition to these structures, the role of proteinase in virulence (Depiazzi \& Richards, 1979; Stewart, 1979; Every, 1982) should also be taken into account. In this respect, the low virulence variant A198M is of particular interest because it has the same proteinase characteristics as the highly virulent strains (Every, 1982) and the only structural distinction of this variant from virulent strains is the low number of pili. Thus abundant pili on $B$. nodosus may be essential for full virulence of the organism to be expressed.

The bovine isolates have abundant pili and an additional layer, and their low virulence could be attributed to either lack of DPM (Table 1) or their distinctive proteinase characteristics (Every, 1982). The total lack of any virulence in variant $91 \mathrm{C}$ could be attributed to three features: its very low proteinase activity (Skerman et al., 1981; Every, 1982), its almost complete lack of pili or its lack of an additional layer.

The function of $B$. nodosus surface structures in virulence is not known. However, Every (1979) has shown that $B$. nodosus pili are most like the group 4 type pili defined by Ottow (1975) which promote non-flagellar surface translocation of bacteria (MacRae et al., 1977). This supports the suggestion (Walker et al., 1973) that pili aid the spread of bacteria within the 

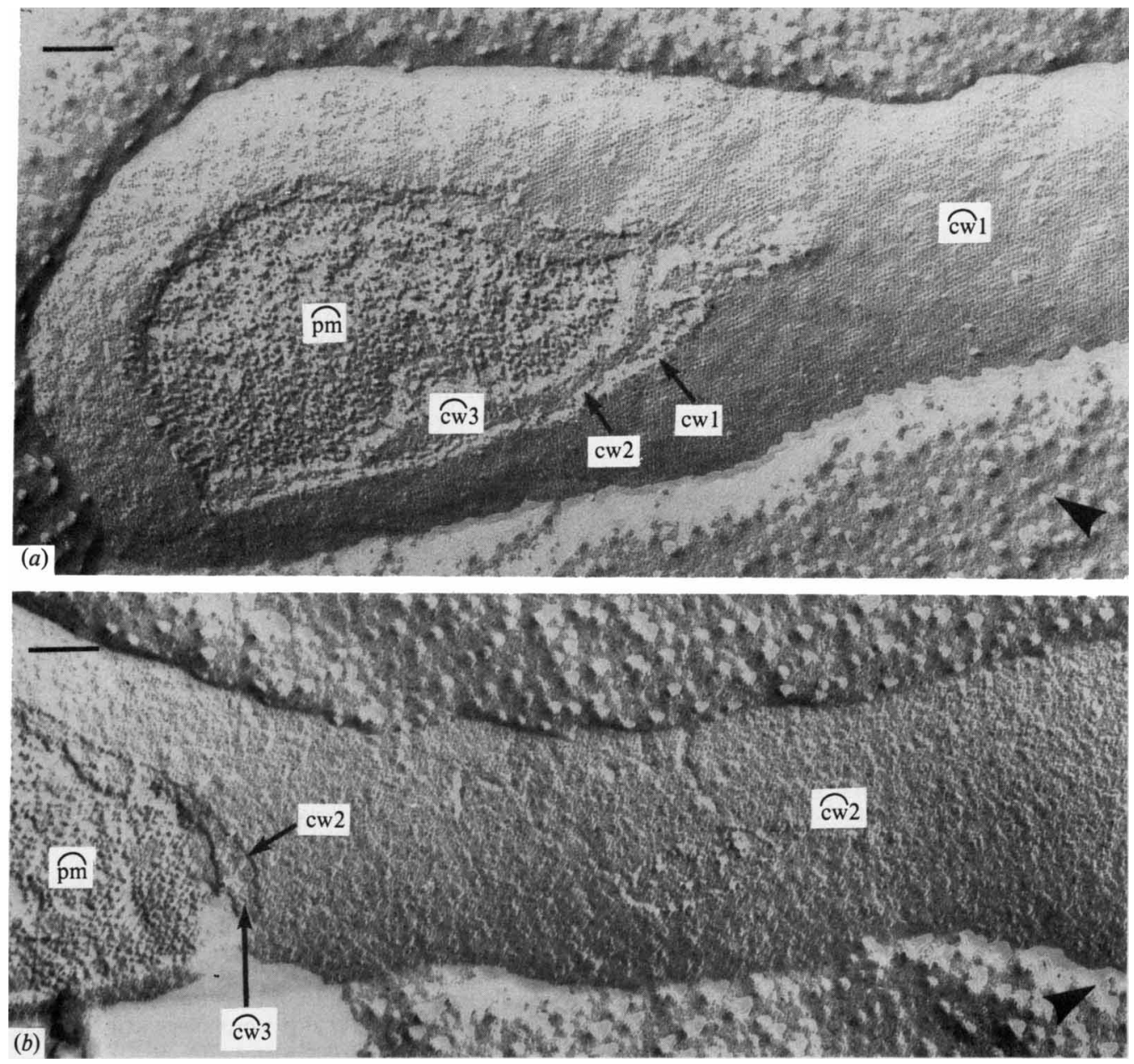

Fig. 9. (a) Convex view of the cell envelope of $B$. nodosus culture variant $91 \mathrm{M}$ obliquely fractured and etched in the absence of glycerol. The etched outer surface of the additional layer (cw1) has hexagonally arranged subunits. (b) Convex view of the cell envelope of $B$. nodosus variant $91 \mathrm{C}$ obliquely fractured and etched in the absence of glycerol. Note the absence of a regularly arranged surface layer and an edge corresponding to additional layer. The etched outer surface is that of the outer membrane (cw2).

epidermal matrix of the sheep hoof. It appears that $B$. nodosus pili do not have an adhesive function (Stewart, 1975) as in some other bacteria (Ottow, 1975). However, the additional layer may have a role in adhesion of $B$. nodosus to sheep or cattle epidermis. In the fish pathogen, Aeromonas salmonicida, the presence of an additional layer was correlated directly with virulence and adhesion to fish tissue. Udey (1978) and Costerton et al. (1974) suggested that the additional layer may function in adhesion of Gram-negative rumen bacteria to a surface.

The low numbers of pili on the $B$. nodosus colony variants could explain their weak immunoprotective activity in challenged sheep, and is consistent with sheep being protected against foot-rot by vaccines containing partially purified pili (Stewart, 1978) or pili preparations of greater than $99 \%$ purity (unpublished data). Although most sheep vaccinated with the culture variants were susceptible to foot-rot challenge there was still a significant reduction in the severity of the infection (Skerman et al., 1981). This could not be attributed to pili or the additional layer because these components were not found in variant $91 \mathrm{C}$. Nevertheless, unassembled subunits of pili or additional layer might still occur as antigens in the cell envelope of variant $91 \mathrm{C}$. Whether such subunits or any of the structures known to be retained by variant 91C, such as DPM, prs, small ring structures and other outer membrane components, can account for the partial protection observed with variant $91 \mathrm{C}$ needs further investigation. 
We thank N. E. Flower, W. S. Bertaud and S. M. O'Kane for their expert help and advice in preparing and interpreting freeze-etch material. We also express our gratitude to J. L. N. Williams for cutting the thin sections.

\section{REFERENCES}

BeVERIDGe, W. I. B. (1941). Foot rot in sheep: a transmissible disease due to infection with Fusiformis nodosus (n. sp.). Studies on its cause, epidemiology and control. Bulletin of the Council of Scientific and Industrial Research of Australia, no. 140, 1-56.

Cagle, G. D., Pfister, R. M. \& Vela, G. R. (1972). Improved staining of extracellular polymer for electron microscopy; examination of Azotobacter, Zoogloea, Leuconostoc, and Bacillus. Applied Microbiology 24, 477-487.

Costerton, J. W., Damgaard, H. N. \& Cheng, K. J. (1974). Cell envelope morphology of rumen bacteria. Journal of Bacteriology 118, 1132-1143.

DEPIAZZI, L. J. \& RICHARDS, A. B. (1979). A degrading proteinase test to distinguish benign and virulent ovine isolates of Bacteroides nodosus. Australian Veterinary Journal 55, 25-28.

Egerton, J. R. \& Parsonson, I. M. (1969). Benign foot rot. A specific interdigital dermatitis of sheep associated with infection by less proteolytic strains of Fusiformis nodosus. Australian Veterinary Journal 45, 345-349.

EVERY, D. (1979). Purification of pili from Bacteroides nodosus and an examination of their chemical, physical and serological properties. Journal of General Microbiology 115, 309-316.

Every, D. (1982). Proteinase isozyme patterns of Bacteroides nodosus: distinction between ovine virulent isolates, ovine benign isolates and bovine isolates. Journal of General Microbiology 128, 809812.

EVERY, D. \& SKERMAN, T. M. (1980). Ultrastructure of the Bacteroides nodosus cell envelope layers and surface. Journal of Bacteriology 141, 845-857.

LAING, E. A. \& EgERTON, J. R. (1978). The occurrence, prevalence and transmission of Bacteroides nodosus infection in cattle. Research in Veterinary Science 24, 300-304.

MacRaE, T. H., Dobson, W. J. \& McCurdy, H. D. (1977). Fimbriation in gliding bacteria. Canadian Journal of Microbiology 23, 1096-1108.

MOOR, H. \& MÜHLETHALER, K. (1963). Fine structure in frozen-etched yeast cells. Journal of Cell Biology 17, 609-628.

OTTow, J. C. G. (1975). Ecology, physiology, and genetics of fimbriae and pili. Annual Review of Microbiology 29, 79-108.

ShORT, J. A., THORLEY, C. M. \& WALKER, P. D. (1976). An electron microscope study of Bacteroides nodosus: ultrastructure of organisms from primary isolates and different colony types. Journal of Applied Bacteriology 40, 311-315.

SKERMAN, T. M. (1975). Determination of some in vitro growth requirements of Bacteroides nodosus. Journal of General Microbiology 87, 107-119.

Skerman, T. M., Erasmuson, S. K. \& Every, D. (1981). Differentiation of Bacteroides nodosus biotypes and colony variants in relation to their virulence and immunoprotective properties in sheep. Infection and Immunity 32, 788-795.

Sleytr, U. B., ThORnley, M. J. \& Glauert, A. M. (1974). Location of the fracture faces within the cell envelope of Acinetobacter species strain MJT/F5/5. Journal of Bacteriology 118, 693-707.

STEWART, D. J. (1975). Studies on the morphology and antigenic structure of Fusiformis nodosus. Ph.D. thesis, University of Sydney, Australia.

STEWART, D. J. (1978). The role of various antigenic fractions of Bacteroides nodosus in eliciting protection against foot rot in vaccinated sheep. Research in Veterinary Science 24, 14-19.

StEWART, D. J. (1979). The role of elastase in the differentiation of Bacteroides nodosus infections in sheep and cattle. Research in Veterinary Science 27, 99-105.

Thomas, J. H. (1962). The differential diagnosis of foot rot in sheep. Australian Veterinary Journal 38, 159163.

THORLEY, C. M. (1976). A simplified method for the isolation of Bacteroides nodosus from ovine foot rot and studies on its colony morphology and serology. Journal of Applied Bacteriology 49, 301-309.

ThORLEY, C. M. \& Egerton, J. R. (1981). Comparison of alum-absorbed or non-alum-absorbed oil emulsion vaccines containing either piliate or non-piliate Bacteroides nodosus cells in inducing and maintaining resistance of sheep to experimental foot rot. Research in Veterinary Science 30, 32-37.

UDEY, L. R. (1978). An additional cell wall layer associated with virulence of the fish pathogen, Aeromonas salmonicida. Abstracts of the Annual Meeting of the American Society for Microbiology B66, p. 24.

Walker, P. D., Short, J., Thomson, R. O. \& ROBERTS, D. S. (1973). The fine structure of Fusiformis nodosus with special reference to the location of antigens associated with immunogenicity. Journal of General Microbiology 77, 351-362. 